\title{
An Unstudied Compilation with the Name of Andrew the Apostle
}

The non-canonical Acts of Andrew the Apostle are among the earliest and most valuable sources for the history of translated literature in medieval Bulgaria. It is a widely accepted view that the archetypal Greek text of Acta Andreae originated in the $2^{\text {nd }}$ century in Alexandria ${ }^{1}$. There are several works that have reached our time in Coptic, Armenian, Syrian, Arabic, Ethiopic, Latin, Greek and Slavic copies in various versions, often in fragments ${ }^{2}$. It is a well-known fact that Eusebius of Caesarea (ca. 263-339) mentions the text in his Ecclesiastical History (III, 25) with reference to Origen (ca. 184-254). The Greek, Oriental and Latin traditions have been described in detail ${ }^{3}$, investigated and published to a certain degree ${ }^{4}$. A. de Santos Otero published a list of the copies known in Slavic manuscripts ${ }^{5}$. According to F. Thomson (in his analysis of the archaeographical data of A. de Santos Otero $)^{6}$ at least seven or eight different texts that can be attributed to the acts of Apostle Andrew were in circulation in the Slavic tradition: Acta et marti-

\footnotetext{
${ }^{1}$ Jean-Marc Prieur (The Anchor Bible Dictionary, ed. D.N. Freedman, vol. I, Doubleday 1992, p. 246): The Manichean Psalter, which contains some allusions to the content of Acts Andr. (A Manichaean Psalm-Book, ed. by C.R.C. Allberry etc. [Including Psalms by Syrus, Heraclides and Thomas. A Transcription and Translation of the Coptic Text. With Plates.] Stuttgart 1938, p. 142, 143, 192), establishes the $3^{\text {rd }}$ century as the terminus ad quem for the redaction of the apocryphon, but the Acts had to have originated earlier, between 150 and 200, closer to 150 than to 200. The distinctive christology of the text, its silence concerning the historical and biblical Jesus, and its distance from later institutional organization and ecclesiastical rites militate for an early dating. Moreover, its serene tone and unawareness of any polemic against some of its ideas as heterodox, particularly in the area of christology, show that it derived from a period when the christology of the Great Church had not yet taken firm shape. One might repeat here the line of argumentation employed by Junod and Kaestli for locating the Acts of John in the same period. Moreover, Acts John displays several affinities with Acts Andr., such as the literary genre, structure, and theological orientations.

${ }^{2}$ L. Roig Lanzillotta, Acta Andreae Apocrypha. A New Perspective on the Nature, Intention and Significance of the Primitive Text. With 12 Plates, Genève 2007 [http://irs.ub.rug.nl/dbi/4b96033e2328f].

${ }_{3}^{3}$ Clavis Apocryphorum Novi Testamenti, cura et studio M. Geerard, Brepols-Turnhout 1992, p. 135-146.

${ }^{4}$ Cf. the comprehensive publication of J.-M. Prieur: Acta Andreae, vol. I-II, ed. J.-M. Prieur, Turnhout 1989 [= CC.SA, 5-6]. Full bibliography in: The Apocryphal Acts of Andrew, ed. J. N. Bremmer, Leuven 2000, p. 186-189..

${ }_{5}^{5}$ A. de Santos Otero, Die Handschriftlische Überlieferung der altslavischen Apokryphen, vol. I, Berlin-New York 1978, p. 69-83.

${ }^{6}$ F. Thomson, Apocrypha Slavica, SEER 58.2, 1980, p. 256-268.
} 
rum Andreae (BHG 95b); Acta Andreae et Mathiae in urbe anthropophagum (BHG 109-110d) in two translations; a compilation of Acta Andreae (BHG 94-94c and 95) and Martirium Andreae (BHG 97), whose Greek or Slavic origin is impossible to determine; Vita Andreae in the Slavonic Prolog (BHG 101b); Commentarius de Andreae, the earliest copy of which is from the $13^{\text {th }}$ c.; an original Russian writing about the Apostle Andrew, his visit to Russia and the conversion of Russians to Christianity, which was spread in numerous copies between the $15^{\text {th }}$ and $18^{\text {th }}$ centuries ${ }^{7}$. Of all the above works, the paleoslavicists' attention is drawn primarily by the acts of Andrew and Mathew in the land of cannibals, a text that has been translated in modern Bulgarian as well ${ }^{8}$.

The text under discussion in this paper is entitled "From the teaching of Apos-

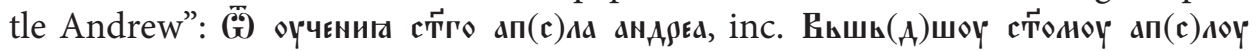

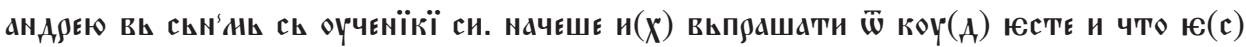
вашє сл⿻(в). It is preserved in a sole copy from the $14-15^{\text {th }}$ C., written in Raška orthography, without nasal vowels, and with one jer ( $\mathrm{b})$. Today the manuscript is preserved in the collection of the Rumyantsev Museum (178), No. 10272, in the Russian State Library in Moscow. The material of the manuscript is bombacyne; it has no visible vergeures and pontuseau and is written out in the Serbian semiuncial, typical for the end of $14^{\text {th }}$ and the beginning of $15^{\text {th }}$ century. Originally it belonged to the collection of A. I. Hludov; however, as evidenced by the number (No. 84) written at the top of the first folio in blue pencil, it had turned up there from the second, so called "Macedonian" collection of A. F. Hilferding. The exceptionally intriguing fate of Hilferding's collection has been studied in detail in the articles of Anatoliy A. Turilov ${ }^{9}$ and Zhanna Levshina ${ }^{10}$. This collection was formed during A.F. Hilferding's trip to Bosnia, Herzegovina, Macedonia and "old" Serbia in 1857,

\footnotetext{
${ }^{7}$ More important publications of Slavic translations and revisions: Н.С. ТИХОнРАвов, Памятники отреченной русской литературы, vol. II. Москва 1863, p. 5-10; St. Novaкović, Apokrifi jednoga srpskog ćirilovskog zbornika XIV vieka, Star 8, 1876, p. 55-69; И.Я. ПорФИРьЕВ, Апокрифические сказания о ветхозаветных лицах и событиях по рукописям Соловеикой библиотеки, СОРЯС $17.1,1877$, р. 87-89; В.Г. ВАСИЛЬЕВСКИЙ, Хождение апостола Андрея в стране мирмидонян, ЖМНП, 1877, vol. 189, pars 2, p. 41-82, 157-185; М.Н. СПЕРАНСКИЙ, Апокрифи ческие Деяния ап. Андрея в славяно-русских списках, ТМАО 15.2, 1894, p. 35-75; С.В. ПетровСКИЙ, Апокрифические сказания об апостольской проповеди по черноморскому побережью, ЗООИД 21, 1898, p. 1-184; П.А. ЛАвРов, Апокрифические тексты, СОРЯС, 67, 1899, series XIV, p. 40-51; К. ИСТомин, Из славянорусских рукописей об апостоле Андрее, Санкт-Петербург 1904, p. 11-14; Н.В. ПоНЫРко, А.М. ПАнченко, Апокрифи о Андрее Первозванном, [iп:] Словарь книжников и книжности Древней Руси, I. ХI-первая половина XIV в., Ленинград 1987, p. 49-54.

${ }^{8}$ Стара българска литература. I. Апокрифи, еd. Д. ПЕткАНОвА, София 1981, p. 185-195, 382383 (Acta Andreae et Mathiae in urbe anthropophagum).

${ }^{9}$ А.А. Турилов, К истории второй (македонской) рукописной коллекиии А. Ф. Гильфердинга, [in:] Славянский альманах 2002, Москва 2003, p. 130-143 [= А.А. Турилов, От Кирилла Философа до Константина Костенеикого и Василия Софиянина, Москва 2011, p. 413-428].

10 Ж. ЛЕвшина, Путешествие А. Ф. Гильфердинга 1868 года и славянские рукописи его «македонской» коллекиии (итоги и перспективы изучения), АрП 34, 2012, p. 77-107. I wish to express my gratitude to Zhanna Levshina for providing me with data concerning the Hilferding collection as well as the text of her article prior to publishing it.
} 
when he was the Russian consul in Sarajevo; later he published a description of the trip ${ }^{11}$. A considerable number of the South Slavic manuscripts were collected by A. F. Hilferding in the Slepče Monastery, the Lesnovo Monastery, in Kratovo, Lešok (Tetovo region), the Treskavec and despot Marko's Monastery as well as in Ohrid, and they probably were sold to A. I. Hludov not later than 1869. The margins of the miscellany contain notes written by A. N. Popov, who worked on the texts; he was also likely to have temporarily kept the book in his collection (today 237 in the Russian State Library). The following inscription has been written out on folio 122v: Понози вожє господину деспоту (God help our master the Despot); the text on folio 133v reads: Гюорьгу двспоту (To Gyurgi the Despot). Probably the ruler in question is Georgi Branković (1427-1456) ${ }^{12}$. The manuscript is cited and examined by a number of scholars in accordance with its description in A.I. Hludov's catalogue (No. 105) ${ }^{13}$ (e.g. Santos Otero mentions it with the same number in his review (No. 31); so does F. Thomson in the review cited above). However, the manuscript has not been in Hludov's collection for the last 70 years, since it is considered to have been acquired by the Rumyantsev Museum prior to 1947.

What is the content of the manuscript? It is a miscellany with mixed content, comprising didactic texts, lives of saints (mostly martyrs), sermons and stories. In the beginning, a fragment has been preserved from The Dispute between Panagiot the Philosopher and Azimit (1r-1v) $)^{14}$; this is followed (folio $2 \mathrm{r}-14 \mathrm{v}$ ) by an excerpt from Siracides (The Wisdom of Sirach) (the beginning is missing, the text resembles the translation in the Izbornik of 1076) ${ }^{15}$; next comes the writing about Apostle Andrew, on which is disscused in this paper $(14 \mathrm{r}-18 \mathrm{v})^{16}$. The texts that come after are as follows: The Epistle of Basil the Great to Gregory the Theologian (18v-25r); The Life of St Protomartyr Stephen (25r-32r); Homily on the Transfiguration by John Chrysostom (32r-36r); Homily on Palm Sunday by John Chrysostom (36v42r); Homily on Mid-Pentecost by John Chrysostom (42r-46v); Homily on the El-

\footnotetext{
${ }^{11}$ А.Ф. ГиЛьФеРдинг, Поездка по Гериеговине, Боснии и Старой Сербии. Босния в начале 1858 г., Санкт-Петербург 1859 [= ЗИРГО, 13].

${ }^{12}$ A Serbian despot (1427-56), vassal of the Turks and the Hungarians. In 1439 he fled to Hungary. He took part in an anti-Ottoman coalition (1443-44); regained (1444) his possession, paid tax to the Turks, but in 1454 lost part of his land.

${ }_{13}^{13}$ А.Н. Попов, Описание рукописей и каталог книг иерковной печати библиотеки А. И. Хлудова, Москва 1872, р. 250-252.

${ }^{14}$ The byzantine work is composed immediately after the Second Council of Lyon (1274) and its ideological content is against the Lyon union and the policy of Emperor Michael VIII Palaiologos (1259-1282), sее: А. Попов, Историко-литературный обзор древнерусских полемических сочинений против татинян (XI-XV в.), Москва 1875, p. 238-286. This fragment (may be the earliest copy in South Slavic tradition) is worthy of separate analysis.

${ }^{15}$ Изборник 1076 года, coll. М.С. МушинСКАЯ, Е.А. МИшинА, В.С. ГОЛЫшЕНКО, еd. А.М. МолдОВАН, vol. I-II, Москва 2009².

${ }^{16}$ A transcription of the text is published by M. N. Speranskiy posthumously: М. Н. СПЕРАНСКИЙ, Библиографические материалы А. Н. Попова. Учение ап. Андрея, ЧИОИДР 1889, 3, p. 53-62. The publication does not include an analysis of the eventual sources of the work; a transcription of the Martyrdom of Saints Apostles Peter and Paul of the same manuscript is also published there.
} 
evation of the Holy Cross (anonymous, missing folia between 46 and 47) (46v-48r); The Life of St Eustace Placidus (48r-57v); Martyrdom of Saint Apostles Peter and Paul (57v-66v) ${ }^{17}$; The Life of Prophet Elijah (66v-70r) (abridged text at the end of which the part of the encomium by St Clement of Ohrid is added) Enkomion on the Dormition of the Theotokos by St Clement of Ohrid (70r-71r); The Life of St Pope Sylvester (fragment) (71r-72v); The Life of St. Euphrosynus the Cook (fragment) (73r-73v); The Life of St George (fragment of the old redaction) (74v); excerpts from the sermon (anonymous) (75r-83r); excerpts from the Paterikon (83r-84r), excerpts from The Erotapokriseis by Anastasios of Sinai (84r-88r); Instruction of Father to his Son (88r-92r, folia appear to be missing between 90v and 91r; identical to the copy in the Izbornik of 1076) ${ }^{18}$; excerpts from The story about Barlaam and Josaphat (92r-108r); short Life of St Sava of Serbia (108r-120v ${ }^{19}$; Synaxarion Life of St Simeon Serbian (121r-122v); A Miracle of St. Nicholas of Myra, about his saving the lives of three men (123r-129r); The Life of St. Demetrius of Thessaloniki $(129 \mathrm{v}-135 \mathrm{r}, 74 \mathrm{r}-74 \mathrm{v}$, copy of the old redaction; the text is uncompleted, without an ending). The content of the hagiographies and the homilies has been specified by $\mathrm{K}$. Ivanova ${ }^{20}$ by providing information on the manuscript regarding its number in the Rumyantsev Museum. The author describes the content as a combination of sermons that have been extracted from the Menaion and the Triodion panegyric and, possibly, from a Reading Menaion of the Old Redaction ("staroizvoden cheti-minej"), with a mixed-up calendar sequence ${ }^{21}$.

The prevailing number of texts retain archaic linguistic features from the time of First Bulgarian Kingdom. I will quote only a few examples from the vocabulary of the text: санохотияк 'free will' (Codex Supr., Izbornik 1073, Gregory of Nazianzus $11^{\text {th }}$ c.: саннохотика, санохотия; Izbornik 1076: санохотью); санновластьць 'absolute' (Codex Supr.); таиник' 'keeper of the secrets' - шБла(A)ающал зенльныняни. таиниика нБ(c)ныль (Gregory Naz. $11^{\text {th }}$ c.; Codex Supr. таивьникь;

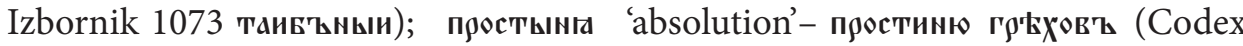

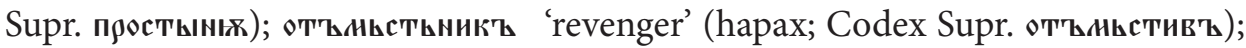
несыт'ы 'greedy' (Codex Supr., Prophetologion, etc.); вдагына 'goodness' (Codex Supr.); валгостына 'benevolence’ (Psalterium Sin., Euchologium Sin., Codex Supr., Prophetologion, etc.); стоүнаство 'shame' (Codex Supr., Life of Alexander the Great), etc. Usage of dual form, along with the use of nominative in the place of accusative case, are quite common.

The examined text is a comprehensive, yet rather brief account of the human history from the Creation to the resurrection of Christ, from the transgres-

\footnotetext{
${ }^{17}$ Published by: М.Н. СПЕРАНСКИЙ, op. cit., p. 1-52.

${ }^{18}$ Изборник 1076 года, р. 164-203.

${ }^{19}$ Д. БогдАНОвИЋ, Кратко житије светог Саве, ЗМСКј 24.1, 1976, p. 5-32.

${ }^{20}$ Кл. ИвановА, Bibliotheca Hagiographica Balcano-Slavica, София 2008, p. 82-83. The author refers the chronology of the manuscript to the last decades of $14^{\text {th }} \mathrm{c}$., defining the font as ustav.

${ }^{21}$ Ibidem, p. 82.
} 
sion to the redemption and salvation (заповъда нань пропов вдати покаганию вь простиню гекұшнь). It starts with an introduction about the place and the circumstances under which Saint Andrew states forth his "teaching", i.e. with stating the grounds for the main compositional part of the text that follows. Andrew and the other disciples answer the questions of the people in front of the "meeting"; by answering the question who they are and what their word is, Andrew denies their assertion that Herod is the true Christ, depicting him as a murderer of children, a deceiver who originates from another tribe and does not belong to the Jews, therefore being their ill-wisher. Andrew declares himself to be the first disciple of John the Baptist, gives an eyewitness account of the baptism of Christ, and confirms that he and the other Disciples of Christ have been sent to preach penance and absolution of sin among all peoples. The main sermon of the Apostle Andrew before the people starts the next day. In it, he traces the events since Creation. The removal of the tenth angelic rank, and its elder, who became the forefather of evil of its own will, is an important issue (санохотию, вако сановластьць). In the text, he is referred to as "the devil"; the name "Satan" or "Satanail" is missing. Man was created in place of the fallen rank of angels in the image and likeness of God and endowed by God with power over all things, over earthly riches and heavenly mysteries, and with immortality. The next part is devoted to the seduction of the first people by the guileful devil, the birth of Cain and his transgressions. Cain's sins are not only listed in the text, but also characterized by examples. Further, the story relates the Old Testament events from the kin of Abel to the flood and the survival of the family of Noah. The anonymous compiler focuses on the worship of pagan idols and Abraham's rejection of pagan customs, the extension of Abraham's offspring, the escape of Joseph to Egypt and the Exodus of the Jews to the Promised Land with Moses; Joshua, Samuel, David and the prophet Daniel are mentioned. The final part tells of the birth and deeds of Jesus until his death on the cross and the resurrection - for the salvation of men and the destruction of the devil. The text ends with an eschatological perspective of the Second Coming and the Last Judgment.

There is no trace of rhetoric in the style: the story is a simple narrative. The introduction, which refutes Herod's role and disguises his origin, undoubtedly bears a resemblance to the initial part of Acta Andreae. I had at my disposal a Georgian text translated into Russian ${ }^{22}$, the comparison with whose introduction showed a close concurrence, even regarding the rendering of names. As noted by researchers of the Greek text, a homily in the synagogue of the town of Amasea is depicted here, whereas the Georgian text relates of the town of Sinop (the capital of the Pontic rulers in Paphlagonia). In our copy no name of a town is mentioned, while the synagogue is referred to as "сьньди' introduction reveals a bias towards polemic; it is obvious that Apostle Andrew is speaking to Jews.

${ }_{22}$ Житие св. апостола Андрея первозванного, ХЧ 8, 1869, p. 151-180. 
The narrative of the Old Testament story has many parallels with the Palaea Historica. Here are some of them:

1) There are similar reasons and the manner of the revolt of the tenth angelic rank, and its elder - out of envy of the perfect and wealthy deeds of God (NE стрьпьвь Богатысттва толикы(X) Бйгыньь); a reluctance to glorify God because of

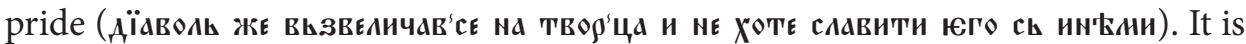
emphasized twice that it is the elder's own will to turn into an evil force (санохотию шьјати се на зАю, ғако сановластьць). The allegation that initially there was dark-

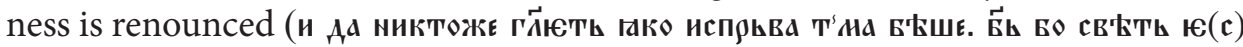

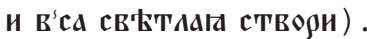

2) Man was created in the place of the fallen angelic rank, and was endowed with

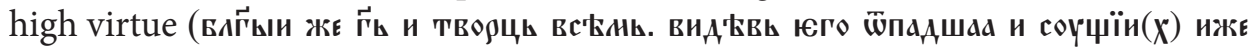

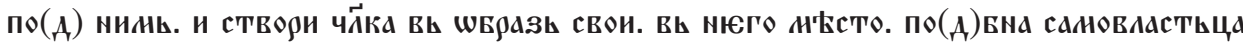

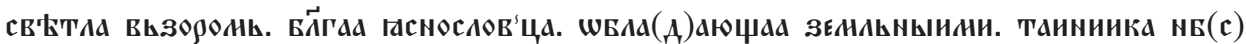

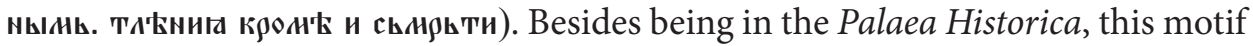
has found a place in one of the versions of the Legend of the Tiberian Sea as well:

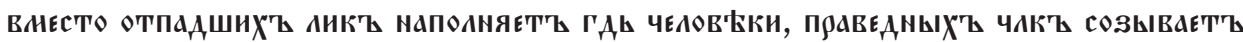

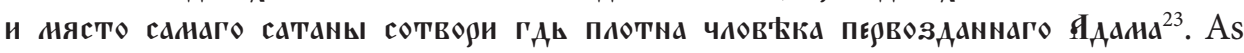
witnessed by Euthymius Zigabenus, the same motif (possibly of a Gnostic origin), alluded to in the Book of Enoch ${ }^{24}$, has found its place in the Bogomil teaching, although slightly modified ${ }^{25}$.

3) The motif of the devil tempting Adam and Eve, and the birth of Cain, are also similar to the Palaea story, despite being much shorter; man was created innocent and immortal, but tempted into evil ways by the devil, whose aim was to tempt the very first of the humans so that the next generations would also turn

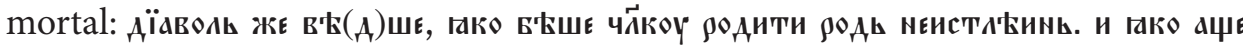

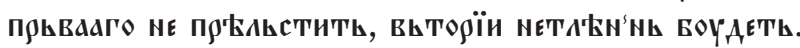

4) Abel's murder and the seven sins of Cain also parallel the Palaea Historica. However, in contrast to the Palaea (as already mentioned), each sin is represented here with a much more detailed characteristic and in two parallel sequences: clarification (interpretation) of each sin and the indication of the respective punishment received for it by Cain. This most detailed part of the examined text bears a certain similarity to some interrogation-response works; however, they are not characterized by such exhaustiveness.

5) The narrative about Abel's offspring is a continuation of the theme about the evil acts of the devil, among which the destructive role of wars is pointed out (the same might be referred to the Bogomils' view of life as well).

\footnotetext{
${ }^{23}$ Й. ИванОв, Богомилски книги и тегенди, София 1925, р. 297.

${ }^{24}$ Ibidem, p. 172, 189.

${ }^{25}$ The Bogomils say that the fallen angels, on hearing that Satanail had promised the Father to replace them by human beings in Heaven, started copulating with human daughters, in the hope of returning to Heaven. Of this mixing the giants were born, see: PG, vol. 130, col. 1305.
} 


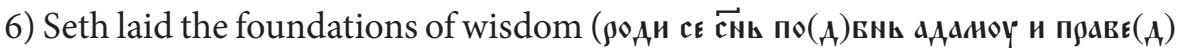

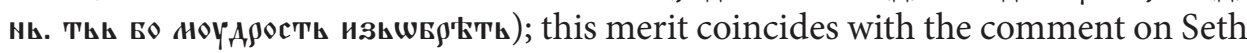
in one of the versions of the Palaea Historica ${ }^{26}$ as well as with the questions and answers, where the creation of the writing is credited to him $^{27}$.

7) The remaining events from the Old Testament are selected with a similar tendency so as to end the work with the birth of Christ, His Crucifixion and Resurrection.

As evidenced by this brief review, no extreme dualistic notions are to be found in the text. Its structure is a combination of narrative and sermon, without any special emphasis on the latter. The "teaching" of the Apostle Andrew is focused on the evil acts of Cain, which doom humanity to a bond with the devil and must therefore be eradicated, as well as on absolution and salvation. The text has undoubtedly been created as a compilation, in which parts of Acta Andreae have been used, and aiming at a framework to contrast good and evil by means of the biblical legend. Until now, a source of Greek analogue of this sole copy has not been found. The text is surrounded by works of a paraenetic nature, such as The Wisdom of Sirach and The Epistle of Basil the Great to Gregory the Theologian. The overall content of the miscellany aims at perfecting the faith by means of moralizing models (we may include in their number the multitude of saints' lives as well). Our conclusion raises the issue of whether or not the examined text can be defined as an apocryphal story. I would refer its composition to the so called type "retelling the Bible"28 or rewriting / recreating the Holy Scripture; these works are also categorized recently as "parabiblical literature" 29 . The patterns of these texts are rooted in the Holy Scripture and mostly in the Gospels' text, which contains stable patterns based on plain analogies, meant to illustrate certain didactic maxims. By incorporating elements of the "marginal" texts into ones of higher authority and didactic value, the former are rendered equal to the latter with regard not only to their reception, but their importance as well. Thus the differences between canonical and non-canonical may entirely disappear.

\section{Appendix}

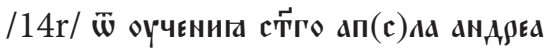

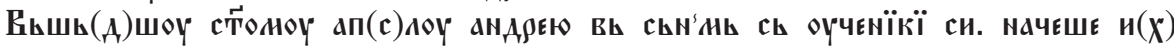

\footnotetext{
${ }^{26}$ Collection of Josifo-Volokolamsk monastery, № $551,16^{\text {th }} \mathrm{c}$.

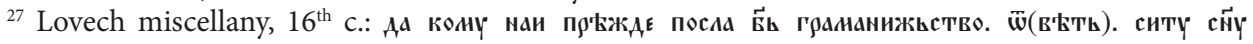
адаAнВоY.

${ }^{28}$ F. Alexander, Retelling the Old Testament, [in:] It is Written: Scripture Citing Scripture. Essays in Honor of Barnabas Lindars, ed. D.A. Carson and H.G.M. Williamson, Cambridge 1988, p. 116118.

${ }^{29}$ G.J. Brooke, Hypertextuality and the "Parabiblical" Dead Sea Scrolls, [in:] In the Second Degree: Paratextual Literature in Ancient Near Eastern and Ancient Mediterranean Culture and Its Reflections in Medieval Literature, ed. P. Alexander, A. Lange and R. Pillinger, Leiden-Boston 2010, p. 43-64.
} 


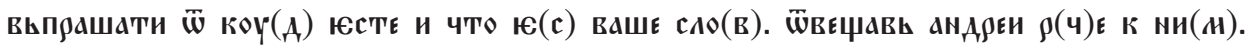

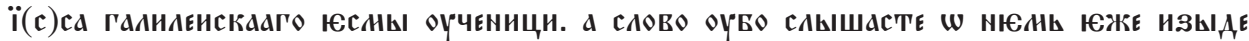

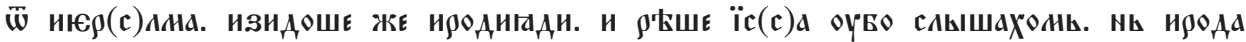

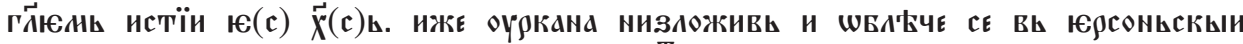

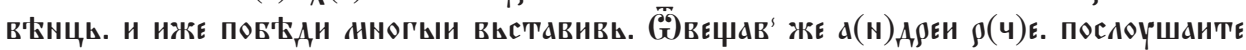
НЕNE. И $\rho($ А

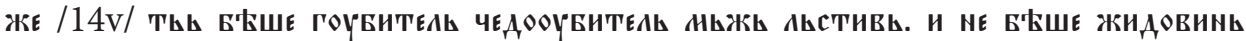

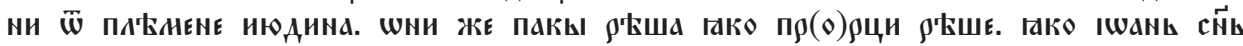

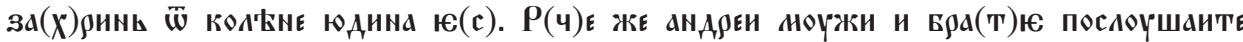

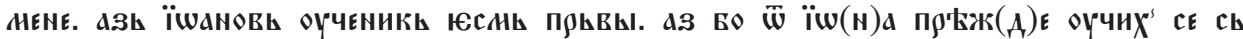

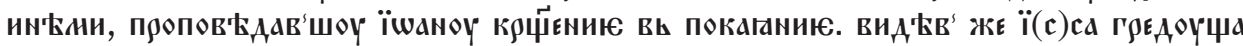

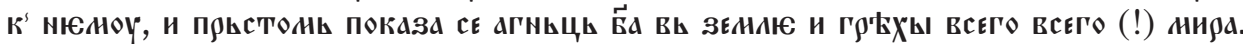

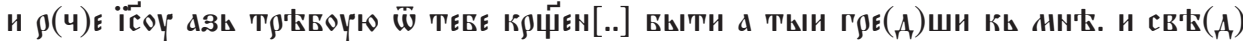

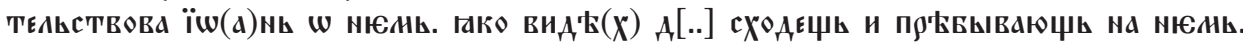

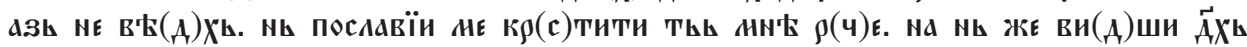

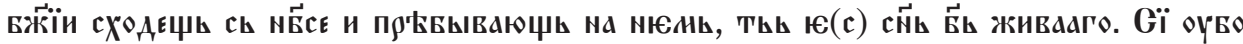

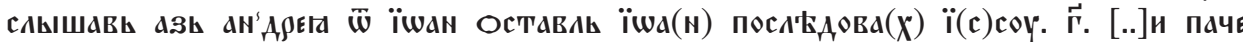
чю(А)са нногаа стТо

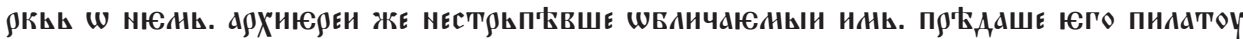

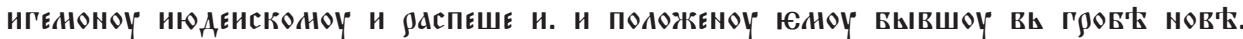

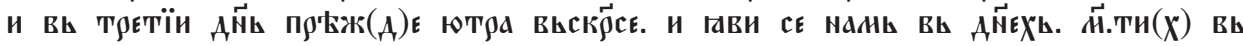

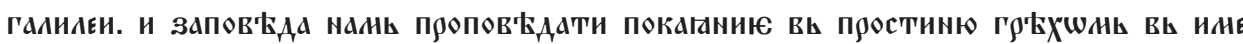

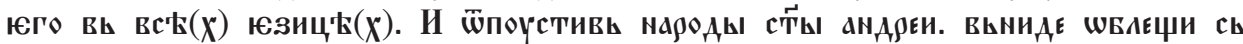

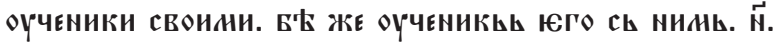

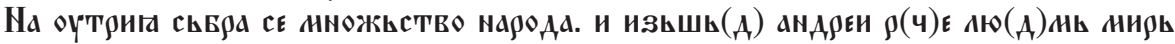
ВАНЬ БЛА(Т)Ю. ШНИ ЖЕ

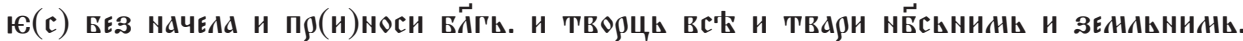

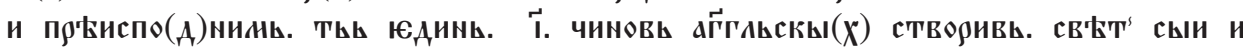

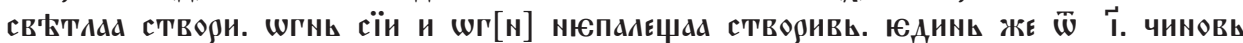

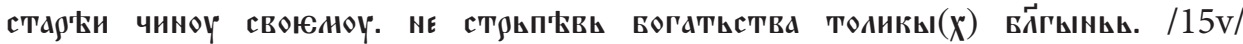

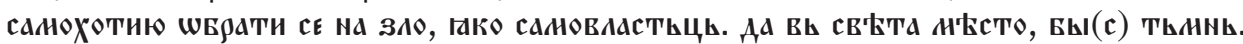

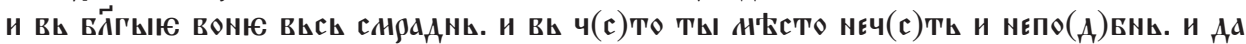

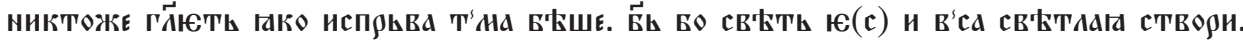

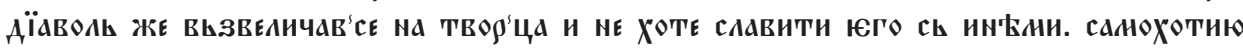

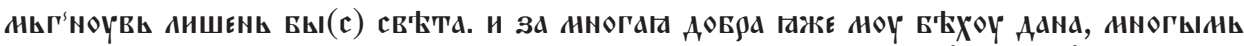

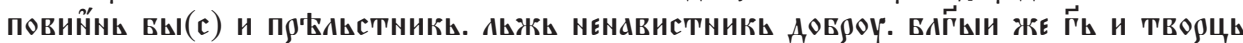

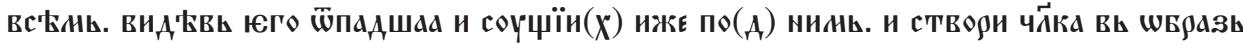

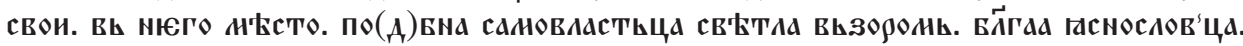

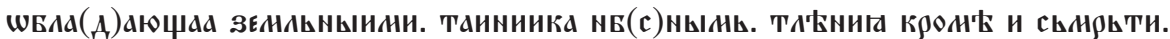

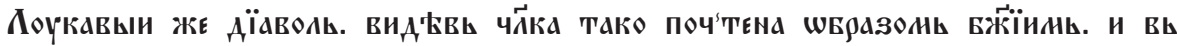

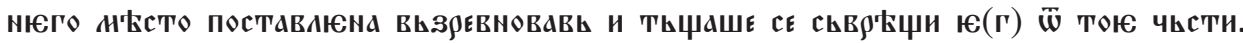

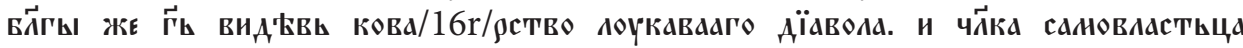

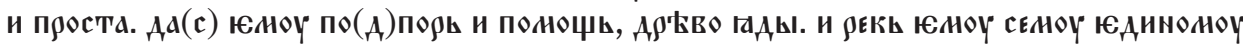

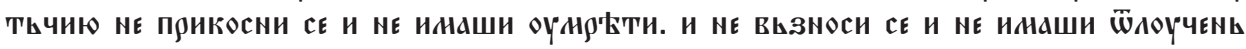




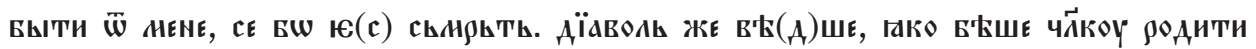

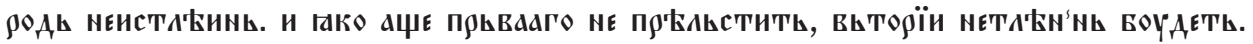

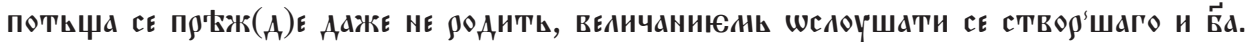

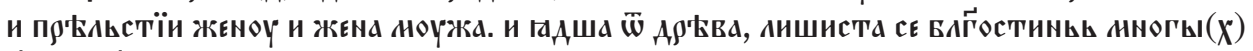

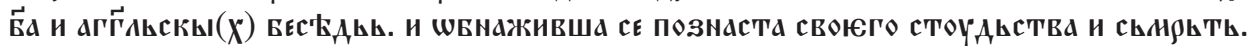

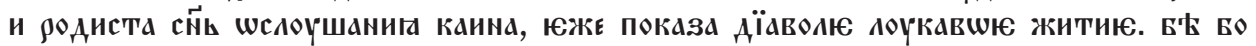

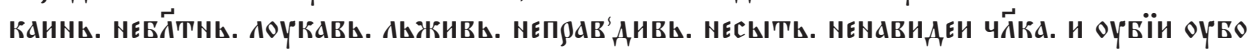

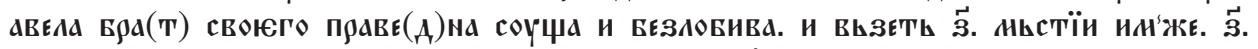

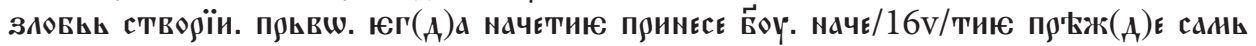

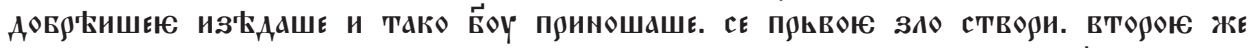

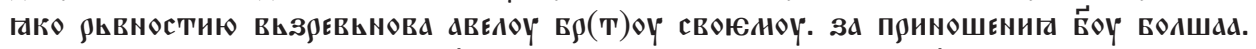

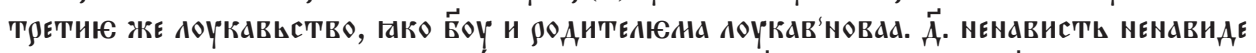

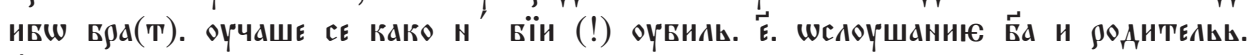

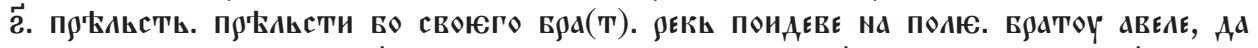

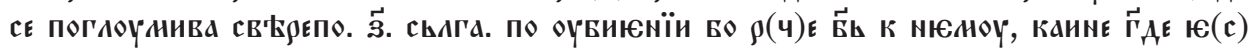

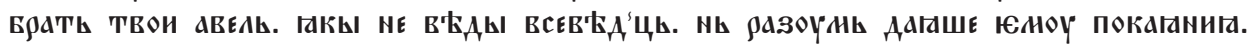

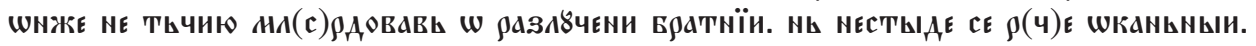

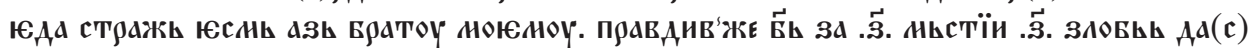

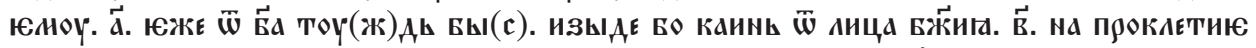

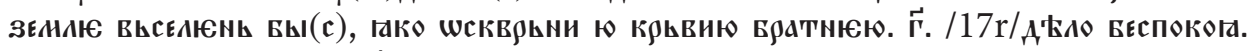

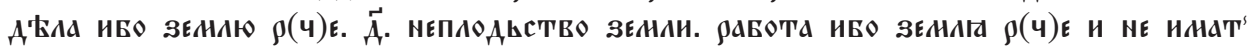

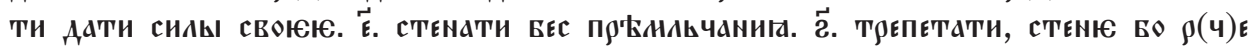

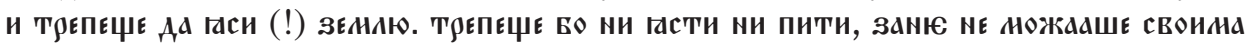

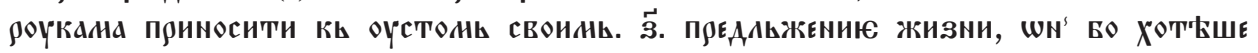

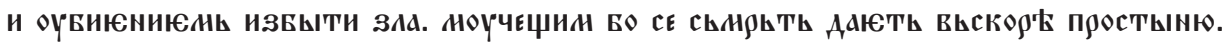

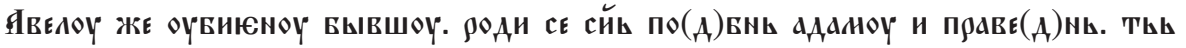
Бо ноүА९ость изышб

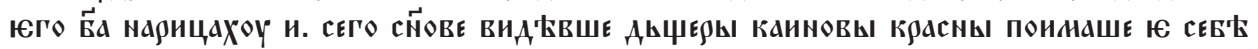

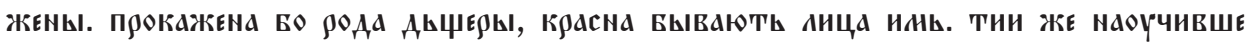

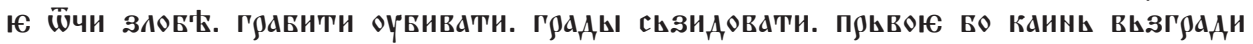

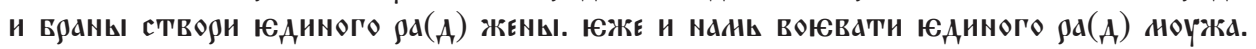

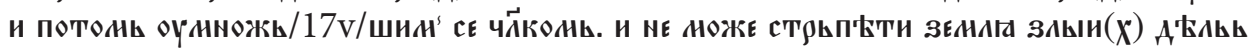

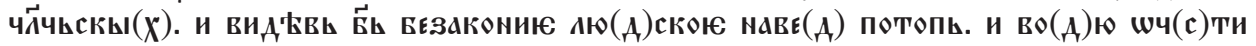

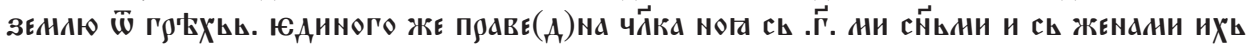

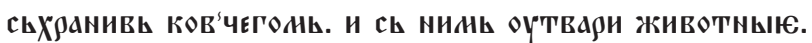

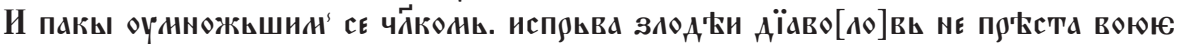

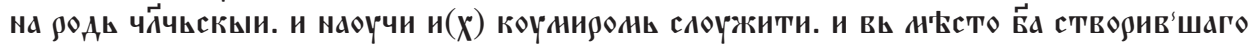

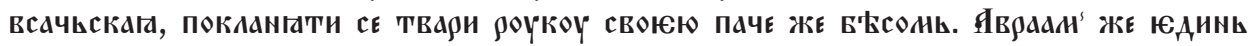

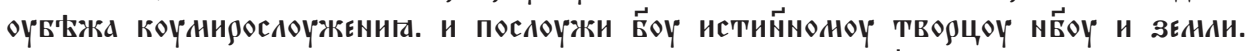

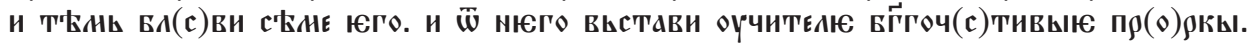

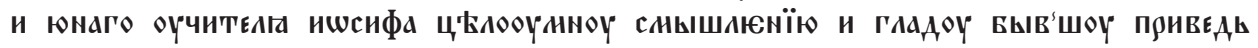

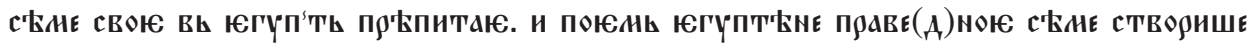

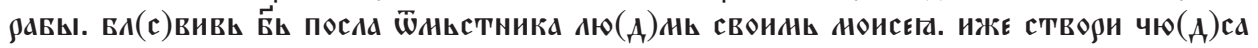




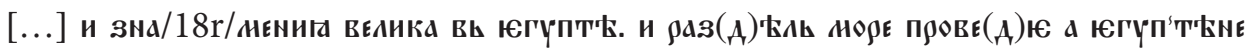

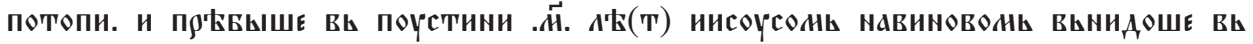

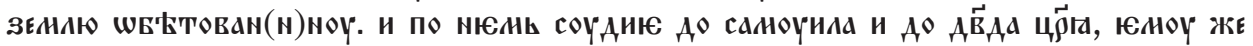

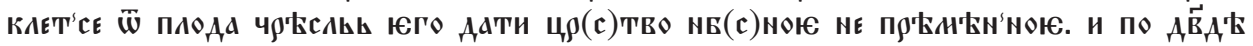

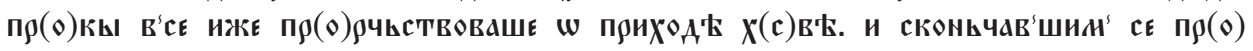

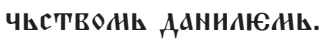

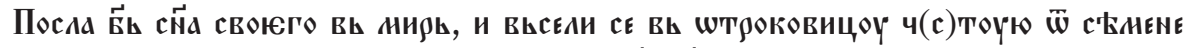

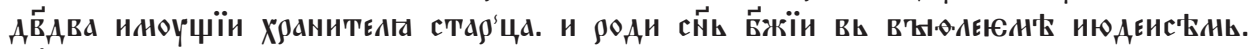

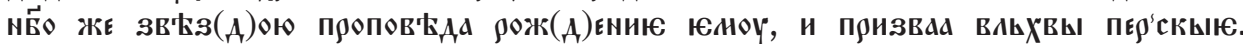

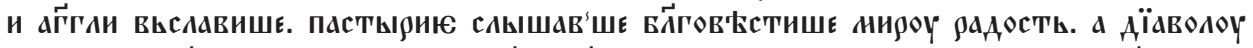

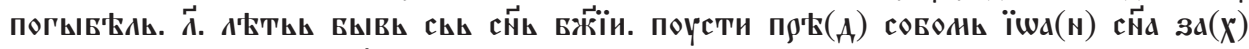

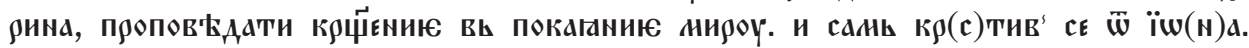

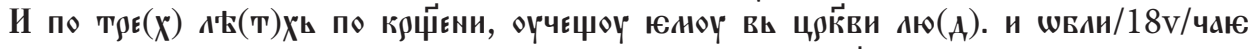

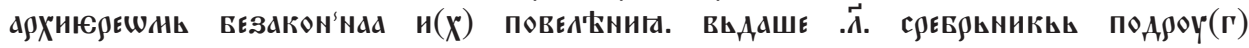

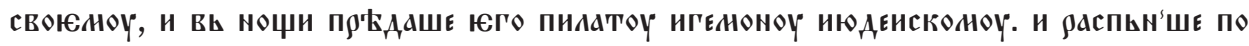

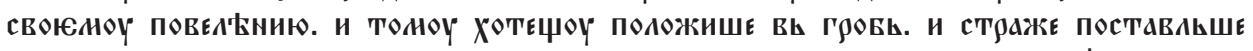

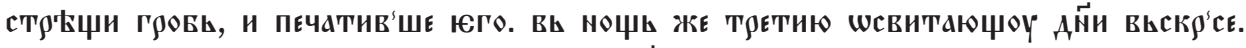

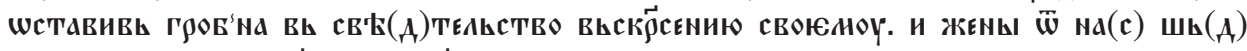

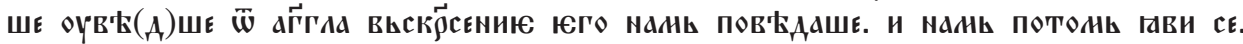

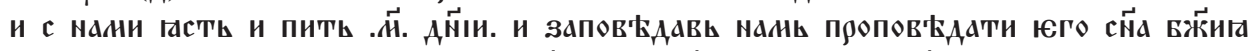

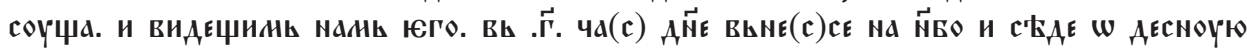

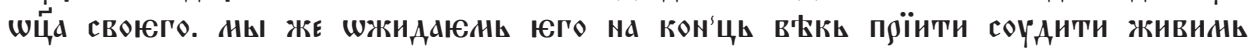

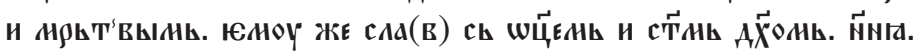

Abstract. The paper presents an unstudied text with the name of the Apostle Andrew in the miscellany of $15^{\text {th }}$ c., now Muz.10272, Rashka orthography. The text (with traces of archaic archetype) is a unique copy of the compilation. The history of the manuscript is very interesting, because it belonged to the A. Hilferding collection in the past. The aim of the author is to propose a preliminary analysis of the text, its origin and chronology, as well as its context in the Slavic tradition.

Keywords: Apocryphal acts of the apostles, Old-Church-Slavonic literary tradition, text edition.

Анисава Милтенова

Институт за литература

Българска академия на науките бул. Шипченски проход 52, бл. 17

1113 София, България anmilten@bas.bg 